\title{
Socio-cognitive Analysis on the Attitude of Gen Z Towards Malay Language in the Era of Industrial Revolution 4.0.
}

\section{Siti Nurul Jannah Fital, Junaini Kasdan, Faten Khalida Khalid}

To Link this Article: http://dx.doi.org/10.6007/IJARBSS/v11-i6/10120

DOI:10.6007/IJARBSS/v11-i6/10120

Received: 01 April 2021, Revised: 13 May 2021, Accepted: 15 May 2021

Published Online: 02 June 2021

In-Text Citation: (Fital et al., 2021)

To Cite this Article: Fital, S. N. J., Kasdan, J., \& Khalid, F. K. (2021). Socio-cognitive Analysis on the Attitude of Gen Z Towards Malay Language in the Era of Industrial Revolution 4.0. International Journal of Academic Research in Business and Social Sciences, 11(6), 290-306.

\section{Copyright: (c) 2021 The Author(s)}

Published by Human Resource Management Academic Research Society (www.hrmars.com)

This article is published under the Creative Commons Attribution (CC BY 4.0) license. Anyone may reproduce, distribute, translate and create derivative works of this article (for both commercial and non-commercial purposes), subject to full attribution to the original publication and authors. The full terms of this license may be seen at: http://creativecommons.org/licences/by/4.0/legalcode

\section{Vol. 11, No. 6, 2021, Pg. 290 - 306}

Full Terms \& Conditions of access and use can be found at http://hrmars.com/index.php/pages/detail/publication-ethics 


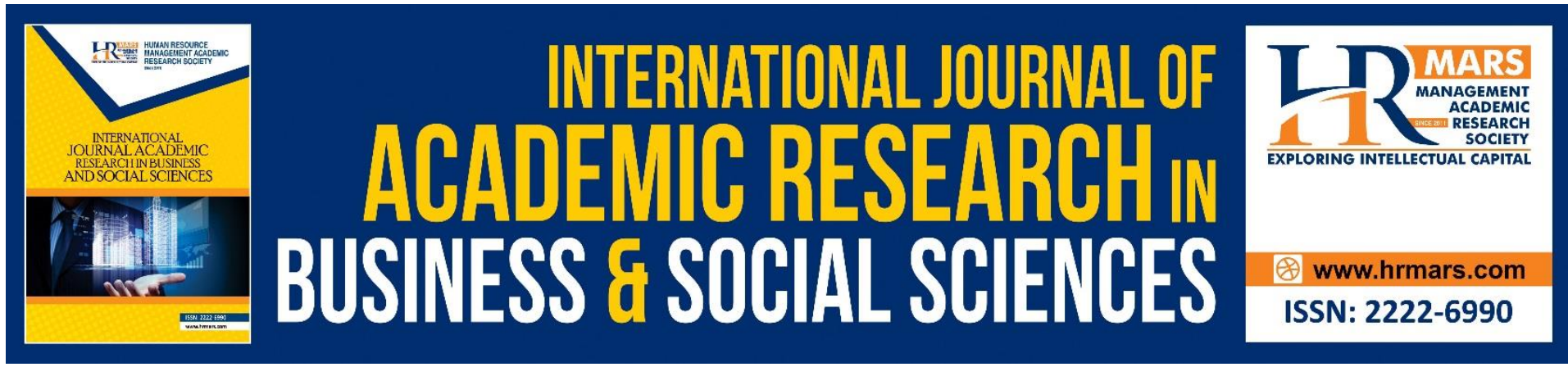

\title{
Socio-cognitive Analysis on the Attitude of Gen Z Towards Malay Language in the Era of Industrial Revolution 4.0.
}

\author{
Siti Nurul Jannah Fital, Junaini Kasdan \\ Universiti Kebangsaan Malaysia, Malaysia \\ Faten Khalida Khalid \\ Universiti Malaysia Perlis, Malaysia
}

\begin{abstract}
The Fourth Industrial Revolution (IR 4.0) which emphasizes more on science and technology and the need to master the area in English seem to impact on the formation of identity of the Malay language. Thus, this study aims to identify and analyze the identity of Malay language among Gen Z, the generation born and grew up in this era. In this respect, appreciation and practice of the Malay language which are the components of identity were also investigated, particularly from the socio-cognitive perspective. Data were obtained from 660 respondents from a survey using Google forms. The respondents consisted of Gen Z throughout Malaysia who received invitations based on set criteria, covering urban, suburban and rural clusters. Research instruments developed specifically for this study have a high level of validity and reliability, namely $\alpha=.75$ to $\alpha=.91$. Data were analyzed descriptively and inferentially using Statistical Package for Social Sciences (SPSS) version 25.0 software. This study utilizes Sociocognitive Theory and Socio-cognitive approach to describe the relationship between Sociocognitive elements with the identity of Malay language among Gen Z. In general, the study concluded that $50.0 \%$ of Gen $Z$ are in the early phase of fading language identity. The study also notes that $62.1 \%$ of Gen $Z$ have negative attitude towards the Malay language, $73.0 \%$ have negative perceptions of the Malay language and $40.0 \%$ have the low practice level of Malay language. However, the study found that $83.4 \%$ of Gen Z have high appreciation of the Malay language. In order to ensure the identity of Malay language among Gen $Z$ can be maintained, the study suggested that the stakeholders in policy-making can make the subject of the Malay language as a compulsory elective course in all higher education institutions, both public or private, as a requirement for graduation.
\end{abstract}

Keywords: Attitude, Identity, Gen Z, Sosciocognitive, Industrial Revolution 4.0

\section{Introduction}

The history of the Fourth Industrial Revolution (IR 4.0) emergence has been introduced by Germany since 2011. Nevertheless, the IR 4.0 came to the world's attention in 2016 when the World Economic Forum declared that the world is currently on the verge of IR 4.0. Malaysia is one of the countries that is moving forward with the development of IR 4.0. It is all about 
the systems and cyber-physical system which brings together the digital world and humans through wireless broadband such as the invention of smart televisions, smartphones and also smarthouse which are available in the market nowadays (Dalmia \& Sharma cited in Razali, Ani $\&$ Tohar, 2020). The involvement of robotics and automation technology has given a new challenge to all sectors in the country. According to llias, K., \& Ladin, C.A. (Noorashid, 2019), in order to maintain competitiveness and to promote the progress in the modern world landscape, all sectors need to make a paradigm shift in accordance with the digital transformation.

The advancement of IR 4.0 is seen to affect the country's education system. All public and private higher institutions are striving to ensure the products produced through the programs offered are accommodating the needs of the IR 4.0-based job market. The revolution which places more emphasis on Science and Technology as well as the necessity to master the area with English is seen to influence the formation of attitude towards Malay language. The technological change in IR 4.0 according to Arndt Graf (2020) is giving an impact on the role and status of Malay language as the national language. Not only that, the researcher also claimed that IR 4.0 also affects the identity of the individual, the concept of Malays and Malaysians. The researcher also stressed that the status of Malay language as the symbol of the speaker's identity will not get affected if proactive efforts are taken to uphold and preserve Malay language by its speakers. Researchers also suggested that Malay language should take up more responsibility as the main language in the IR 4.0.

Over ten years ago, Sani (2007) mentioned that after Malaysia gained its independence nearly 50 years, Malay language continues to be an issue and unresolved problem. Although Malay language has been enacted as the national language known as Bahasa Melayu, practically the status and dignity of the language is still low-ranking. Based on the research, Malay language is defeated by English language, in fact at certain instances, also overthrown by Mandarin language. The Sultan of Perak, Sultan Nazrin Muizzuddin Shah said that;

"...the national language of a country is the identity of a nation state. It is unpleasant and ironic if there is a person who is a citizen, with all the benefits and privileges of a citizen, but unable to understand, to speak, to write or to read in his country's national language."

(Sivamuruga Pandian, 2017)

Why did the Sultan make such a call even though Malaya has gained its independence for more than 60 years? How exactly is the attitude of Malaysians nowadays toward Malay language? What about the attitude towards Malay language among Gen $Z$ after they have gone through the phase of educational policy which emphasized English language? Does the policy which was implemented previously affect their attitude on Malay language? Is yes, how serious is that? These are the things that will be answered in this study.

\section{Methodology}

This study is a descriptive quantitative study that utilizes data obtained from a questionnaire. Research instruments developed specifically for this study have a high level of validity and reliability, namely $\alpha=.75$ to $\alpha=.91$. Data were analyzed descriptively and inferentially using Statistical Package for Social Sciences (SPSS) version 25.0 software. There were two parts of 
the questions asked in the questionnaire. First, part A on the background of the respondents covers aspects of gender, location of residence, race/ethnicity and field of study. Second, part $B$ on the attitude of the respondents which consists of 10 questions with five answer choices namely agree (A), strongly agree (SA), not care (NC), disagree (DA) and strongly disagree (SDA).

\section{Objectives}

Attitude is defined by Allport (cited by Junaini, 2011) as a mental readiness that is structured based on the experiences a person goes through and in turn, dynamically influences an individual's response to all related objects and situations. In this study, attitude is referred to as an assessment, positive or negative, like or dislike, beliefs and behaviours of the $Z$ generation towards Malay language as the national language defined by their way of thinking, feelings, beliefs and behaviours because of the values and norms which are being upheld and practiced. Gen Z's attitude towards the Malay language is a reflection of their affection and pride of the Malay language and concomitantly portray their identity to the Malay language.

Therefore, the study of the Gen Z attitude on Malay language as well as its relationship with the social background is carried out to achieve the following objectives:

i. Identify the identity and attitude on Malay language among the $Z$ Generation.

ii. Elaborate the phenomena of Malay language attitude among Z Generation based on Socio-Cognitive Theory.

\section{Hyipotheses}

The scope of the study conducted by the writer is limited to the following hypotheses:

$\mathrm{H}_{1} \quad$ There is a significant difference with the attitude towards Malay language among Gen Z who has a different social background.

$\mathrm{H}_{2} \quad$ There is a significant relationship between the attitude towards Malay language among Gen Z who have different social backgrounds.

\section{Influence and Relationship between Social Background and the Attitude of Gen Z towards Malay Language.}

Based on the data observed, the study found that the social background of Gen Z in this study such as gender, residential location, race and their field of study affect their attitude on Malay language. This section will analyze the influence of social background toward the Malay language behaviours. Muller (1992) generally defined the word attitude as the influence, rejection, evaluation. like or dislike of a matter. Attitude is a personal element that appears in a person's soul which can influence his beliefs and behaviours. Fishbein and Ajzen (1975) mentioned that attitude is formed based on three main components which is cognitive, affective and psychomotor. Cognitive component deals with knowledge, overviews, confidence i.e. matters relating how a person's perceptions towards the object of attitude. Meanwhile, the affective component deals with the pleasure or displeasure towards the object of attitude. Pleasant feeling is a positive matter, while the unpleasant feeling is something negative. The psychomotor component will link to the tendency to react or behave towards the object of attitude. Overall results showed that Gen Z have a negative attitude towards Malay language with $14 \%$ being very negative and $48 \%$ being negative. Their attitude towards Malay language is shown in Figure 1.0. 


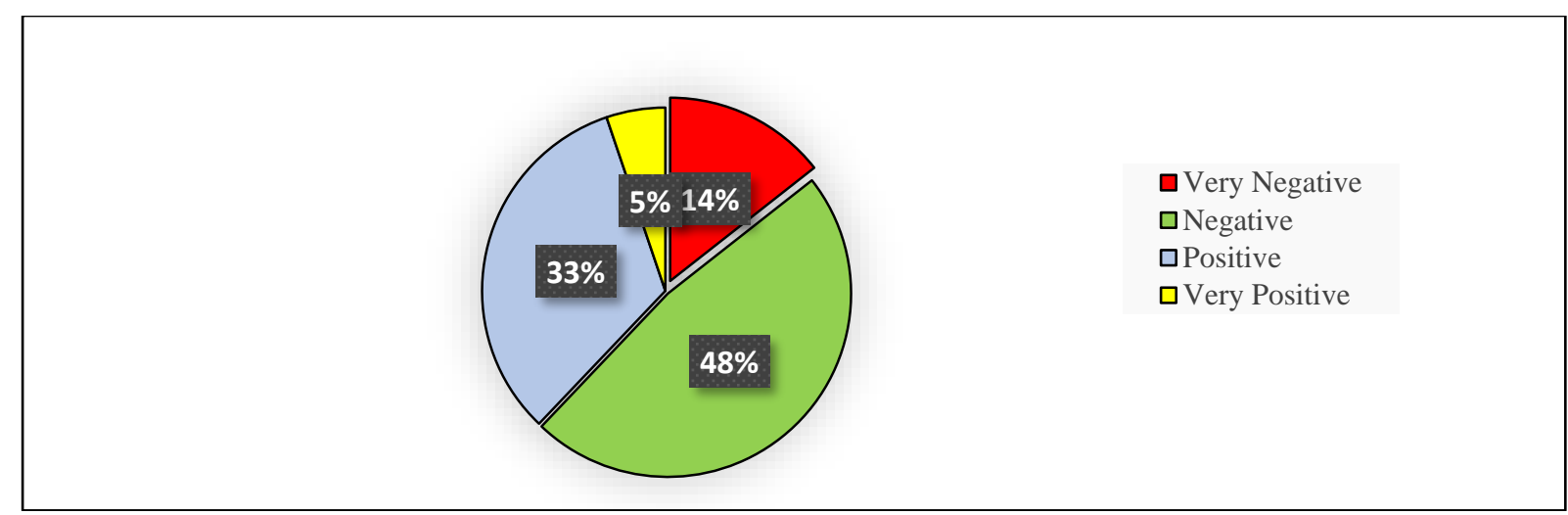

Figure 1.0. The percentage of Gen Z attitude towards Malay

Based on Figure 1.0, generally the majority of Gen Z has a negative attitude towards Malay language. Their attitude can be seen through the attitude items provided in the survey. These items are considered to give an overview on respondents' attitude in detail. For analysis purposes, only items that are contributing to the respondents' highest negative attitude, which is S6 will be discussed. Details of the results from the attitude items tested in the questionnaire to the respondents can be seen in Table 1.0. 
Table 1.0 Percentage of Item Frequency on Gen Z Attitude towards Malay language.

\begin{tabular}{|c|c|c|c|c|c|c|}
\hline \multirow[t]{2}{*}{ Item } & \multirow[t]{2}{*}{ Gen Z Attitude towards Malay language } & \multicolumn{5}{|c|}{ Frequency (\%) } \\
\hline & & SDA & DA & NC & A & SA \\
\hline S1 & $\begin{array}{l}\text { *All advertisements in public places should not } \\
\text { be required to use the Malay language. }\end{array}$ & 21.4 & 22.4 & 19.2 & 24.4 & 12.6 \\
\hline S2 & $\begin{array}{l}\text { All public activities such as student gatherings, } \\
\text { public speeches, etc. do not need to use } \\
\text { English when attended by at a least one } \\
\text { foreigner. }\end{array}$ & 16.2 & 19.2 & 24.1 & 25.6 & 18.8 \\
\hline S3 & $\begin{array}{l}\text { The country's leaders can choose not to use } \\
\text { English or other languages than Malay } \\
\text { language when releasing a public statement to } \\
\text { the local community. }\end{array}$ & 25.0 & 20.3 & 16.1 & 23.0 & 15.6 \\
\hline S4 & $\begin{array}{l}\text { Malay is the most effective language to use } \\
\text { when communicating with friends of different } \\
\text { races. }\end{array}$ & 12.4 & 20.3 & 22.1 & 25.6 & 19.5 \\
\hline S5 & $\begin{array}{l}\text { *Suggestion to make English as the full } \\
\text { medium of instruction at all levels need to be } \\
\text { implemented immediately. }\end{array}$ & 18.2 & 19.4 & 21.7 & 22.3 & 18.5 \\
\hline S6 & $\begin{array}{l}\text { Setting up the requirement to pass the Malay } \\
\text { language as the main requirement of getting a } \\
\text { job in public sector is relevant and does not } \\
\text { need to be abolished. }\end{array}$ & 38.6 & 18.9 & 15.2 & 12.1 & 15.2 \\
\hline S7 & $\begin{array}{l}\text { *The employer from private companies has } \\
\text { the right to decline the passing requirement } \\
\text { for Malay language in the hiring process. }\end{array}$ & 27.3 & 23.9 & 21.5 & 15.3 & 12.0 \\
\hline S8 & $\begin{array}{l}\text { Malay language should be used as the primary } \\
\text { language in all delivery systems at the } \\
\text { entrance to this country. For example, security } \\
\text { announcements on airplanes, airports and so } \\
\text { on. }\end{array}$ & 12.6 & 13.6 & 26.4 & 22.7 & 24.7 \\
\hline S9 & $\begin{array}{l}\text { All important information released by the } \\
\text { government should use Malay language, } \\
\text { regardless of the various races. }\end{array}$ & 15.2 & 22.1 & 27.6 & 21.1 & 14.1 \\
\hline S10 & $\begin{array}{l}\text { The national language if this country cannot be } \\
\text { replaced with English or other languages. }\end{array}$ & 13.6 & 7.9 & 13.2 & 17.6 & 47.7 \\
\hline
\end{tabular}

By looking at the possibility of gender influences on the attitude towards Malay language among Gen $Z$, this study presented a hypothesis that there is a significant relationship between gender and Gen Z's attitude. Nevertheless, the Chi -Square test results, $\chi 2=6.405 a, p=0.093>0.05$, as shown in Table 1.1 indicate that the study obtained sufficient evidence to reject the hypothesis and accept the null hypothesis (HO). Actually, there is no relationship or affiliation between gender and attitude towards the Malay language among 
Gen Z. Based on the table, it can be seen that the distribution of Gen Z's attitude based on gender is almost even, which is between $30.0 \%$ to $50.0 \%$.

Table 1.1. Relationship between Gender and Gen Z's Attitude towards Malay Language.

\begin{tabular}{|c|c|c|c|c|c|c|c|c|}
\hline \multirow[t]{2}{*}{ Gender } & \multicolumn{4}{|c|}{ Attitude\% } & \multirow[t]{2}{*}{ Total } & \multirow[t]{2}{*}{$x^{2}$} & \multirow[t]{2}{*}{$\mathbf{P}$} & \multirow[t]{2}{*}{$\mathbf{w}$} \\
\hline & Very Negative & Negative & Positive & Very Positive & & & & \\
\hline $\begin{array}{l}\text { Male } \\
\text { Female }\end{array}$ & $\begin{array}{l}16.0 \\
12.8\end{array}$ & $\begin{array}{l}45.2 \\
50.3\end{array}$ & $\begin{array}{l}35.2 \\
30.2\end{array}$ & $\begin{array}{l}3.6 \\
6.7\end{array}$ & $\begin{array}{l}332 \\
328\end{array}$ & 6.405 & 0.093 & 0.92 \\
\hline
\end{tabular}

The results of $t$-test showed $t=-0966, p=0.335>0.05$ reinforcing the finding that there was no significant difference among male and female Gen Z towards Malay language. The mean comparison showed a small difference, i.e. -0.1087. Min for women is 5.5707, while the mean for the teenage male is 5.4620 , thus it can be concluded that the attitude of female Gen $Z$ to Malay were more positive than men although the difference is small. The difference between the attitude of male and female Gen $Z$ can be seen through their views on the establishment of the requirement to pass the Malay language as the main condition for getting a job in the public sector as shown in Figure 1.1 below;

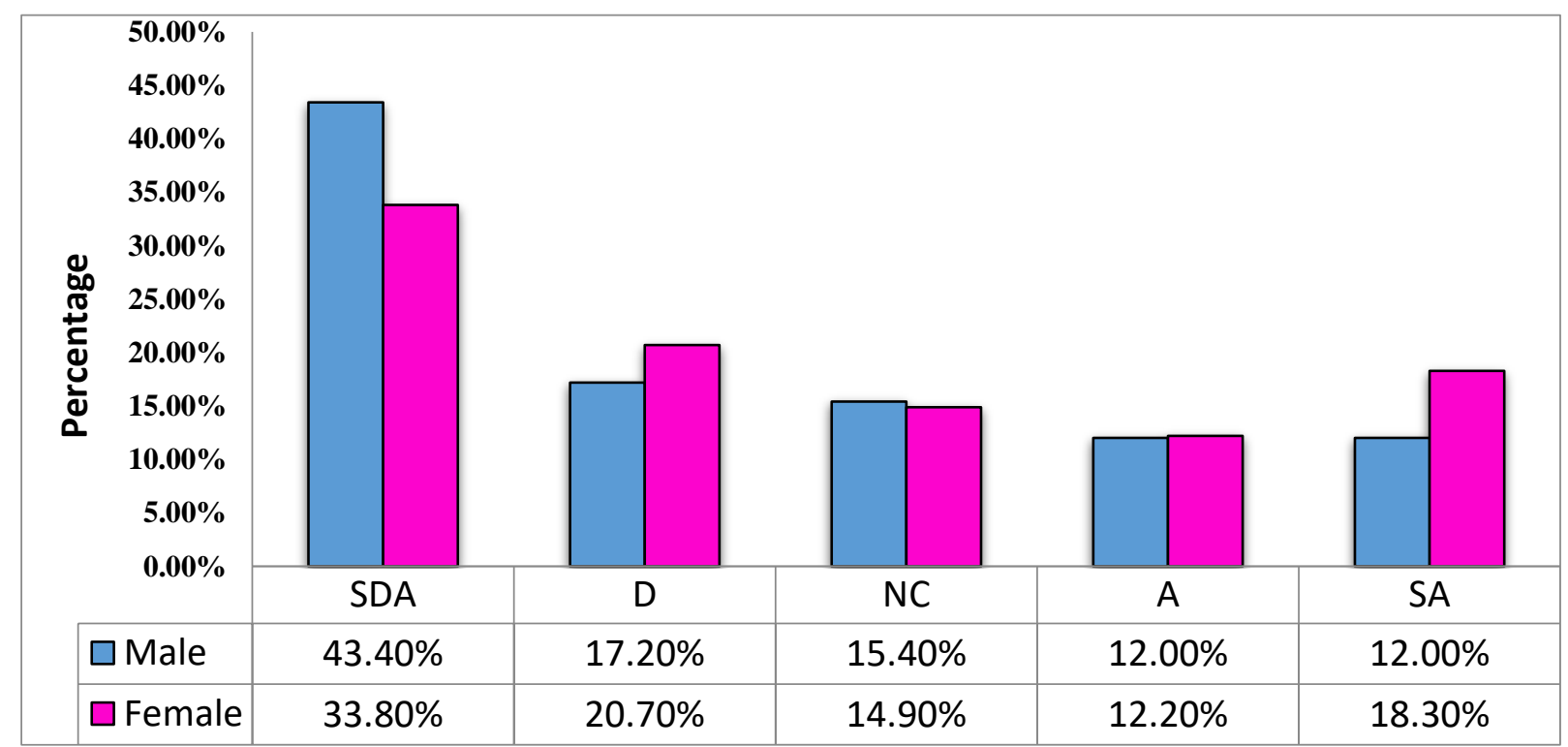

Figure 1.1. Percentage frequency of Gen Z views on item S6 based on gender.

Overall, the analysis shows that the attitude on Malay language among female Gen $\mathrm{Z}$ is more positive compared to the male Gen Z. This is related to the natural traits that exist in women, as discussed by Ismail et al. (2010) i.e. the traits that women have are more obedient than men. The femininity traits often portray seriousness in every activity performed by women, while men are always portrayed to take things for granted. In terms of the satisfaction with something, women are more satisfied if they can conform with the rules set, while men tend to feel satistied if they can break the rules. 
In addition, the observation data shows that gender is not the only social factor which can influence the attitude of Gen Z towards Malay language. There are other contributing factors which influenced their attitude such as location of residence, i.e. urban, suburban and rural areas. The Chi-squared tests were conducted and explained that the youths from rural areas have more positive attitudes towards Malay language compared to those from urban and suburban area despite the disparities are not that big. The results of the Chi-squared test are shown in Table 1.2.

Table 1.2. Relationship between the location and the attitude of Gen Z towards

\begin{tabular}{|c|c|c|c|c|c|c|c|c|}
\hline \multirow[t]{2}{*}{ Location } & \multicolumn{4}{|c|}{ Attitude\% } & \multirow[t]{2}{*}{ Total } & \multirow[t]{2}{*}{$x^{2}$} & \multirow[t]{2}{*}{$\mathbf{P}$} & \multirow[t]{2}{*}{$\mathbf{w}$} \\
\hline & $\begin{array}{l}\text { Very } \\
\text { Negative }\end{array}$ & Negative & Positive & $\begin{array}{l}\text { Very } \\
\text { Positive }\end{array}$ & & & & \\
\hline $\begin{array}{l}\text { Urban } \\
\text { Suburban } \\
\text { Rural }\end{array}$ & $\begin{array}{l}13.6 \\
19.4 \\
9.9\end{array}$ & $\begin{array}{l}50.9 \\
46.3 \\
38.7\end{array}$ & $\begin{array}{l}31.9 \\
26.9 \\
44.1\end{array}$ & $\begin{array}{l}3.6 \\
7.5 \\
7.2\end{array}$ & $\begin{array}{l}389 \\
160 \\
111\end{array}$ & 17.866 & 0.007 & 0.116 \\
\hline
\end{tabular}

Based on the observations data in Table 1.2, the study found that the Gen Z in urban areas have a more negative attitude compared to those in suburban and rural areas. The results of the Chi-squared test, $\chi 2=17.866 a, p=0.007<0.05$, indicate that this study has a solid evidence to reject the null hypotheses (HO) which says that there is no significant association between the residence location and Gen Z's attitude towards Malay language. In fact, the locations of Gen Z's residence are directly related to their attitude on Malay language. Nevertheless, the value of $p(w=0.116)$ indicates that the correlation that occurs is a weal/small correlation.

The results of ANOVA test, $F=4.501, p=0.011<0.05$ reinforce the finding that there are significant differences in attitude among urban, suburban and rural adolescents. Based on PostHoc and Sheffer values the study recorded the mean for urban was 5.4563, the mean for suburbs was 5.4044, while the mean for rural was 5.8865. Based on the mean value, it is found that the attitude of Gen $Z$ towards Malay language in the urban and suburban areas are lower than in the attitude of Gen $Z$ in rural areas. Figure 1.2 below gives a clear picture of the negative attitude of the urban and suburban community towards Malay language. 


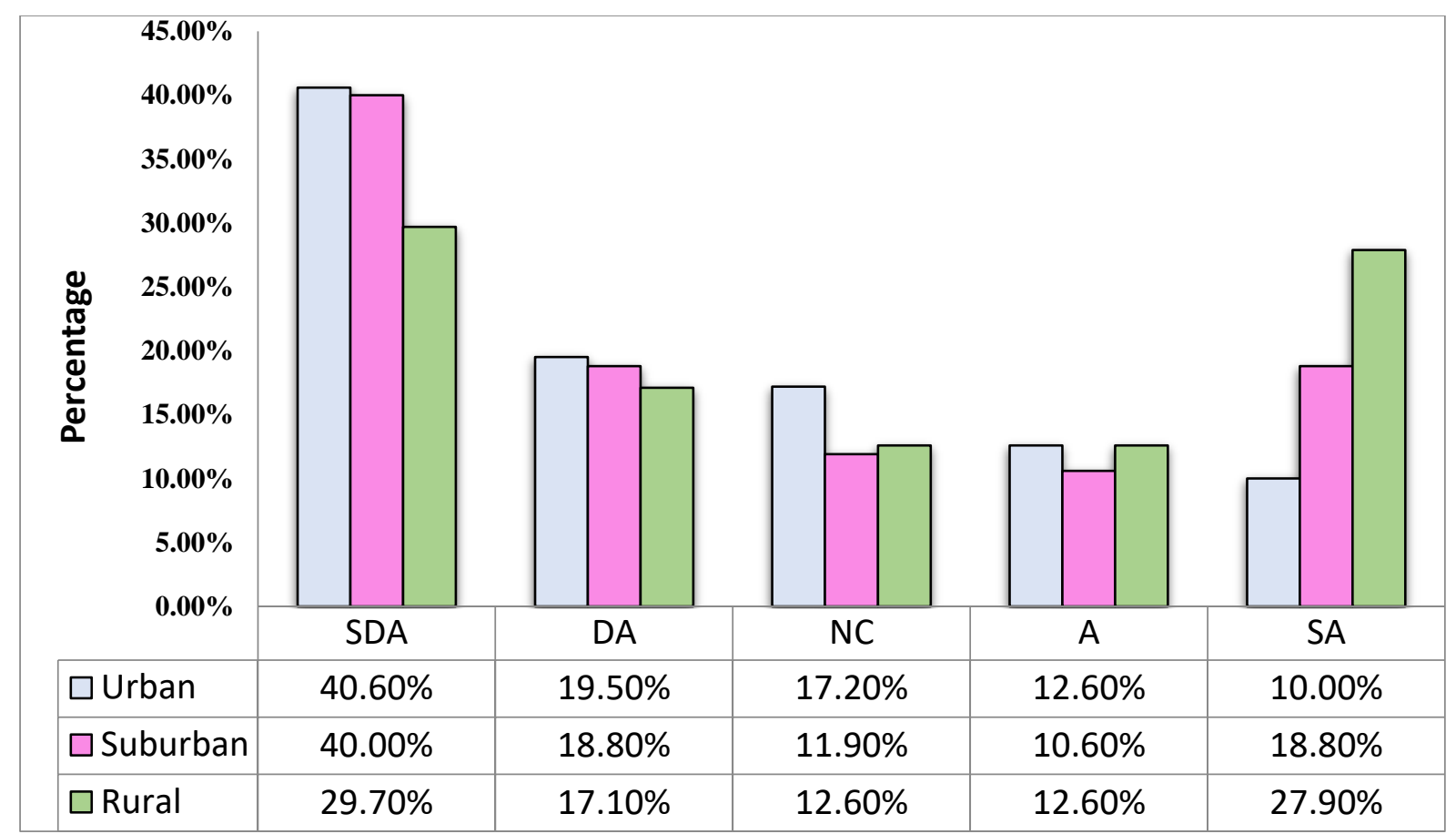

Figure 1.2. Frequency percentage of Gen Z's perceptions on item $\mathrm{S} 6$ based on residence location

Overall, the analysis showed that the attitude of Malay language among Gen $\mathrm{Z}$ in this study who live in urban and suburban areas is more negative than those Gen $Z$ residing in rural areas. Among the reasons for the negative attitude towards Malay language is because Gen $\mathrm{Z}$ in the city have more exposure to foreign languages, especially English which is highly used in urban areas. Besides, their residential location which is in densely developed areas such as the cities with the access to the fast and extensive broadband facilities is also one of the factors that contributes to the high use of English in the area.

Furthermore, the observation found that race is one of the factors that creates the differences in attitudes towards the Malay language among Gen Z. The Chi-squared test found $\chi 2=23.341 \mathrm{a}, \mathrm{p}=0.000<0.05$, have sufficient evidence to reject the null $\mathrm{HO}$ in which there is no significant relationship between the race and the attitude of Gen Z towards Malay language. Nonetheless, the relationship is small with the value of $V$ Cramer $w=0.109$. In general, it appears that the majority of the Gen $Z$ from all races have a negative attitude towards the language. Observations also show that the Chinese Gen $Z$ have the highest negative attitude compared to those from other races. The results of the Chi-squared test are shown in Table 1.3. 
Table 1.3. Relationship between Gen $\mathrm{Z}$ races and their attitudes towards Malay language.

\begin{tabular}{|c|c|c|c|c|c|c|c|c|}
\hline \multirow[b]{2}{*}{ Race } & \multicolumn{4}{|c|}{ Attitude\% } & \multirow[t]{2}{*}{ Total } & \multirow[t]{2}{*}{$x^{2}$} & \multirow[t]{2}{*}{$\mathbf{P}$} & \multirow[t]{2}{*}{$\mathbf{w}$} \\
\hline & $\begin{array}{c}\text { Very } \\
\text { Negative }\end{array}$ & Negative & Positive & $\begin{array}{c}\text { Very } \\
\text { Positive }\end{array}$ & & & & \\
\hline $\begin{array}{l}\text { Malay } \\
\text { Chinese } \\
\text { Indian } \\
\text { Bumiputera }\end{array}$ & $\begin{array}{l}12.3 \\
19.2 \\
18.6 \\
12.2\end{array}$ & $\begin{array}{l}44.4 \\
57.5 \\
49.2 \\
43.9\end{array}$ & $\begin{array}{l}36.7 \\
22.6 \\
27.1 \\
36.6\end{array}$ & $\begin{array}{l}6.5 \\
0.7 \\
5.1 \\
7.3\end{array}$ & $\begin{array}{l}414 \\
146 \\
59 \\
41\end{array}$ & $23.341^{a}$ & 0.000 & 0.109 \\
\hline
\end{tabular}

The results of ANOVA test, $\mathrm{F}=7.834, \mathrm{p}=0.000<0.05$ proved that there are significant differences in attitudes among Gen $Z$ of different races/ethnicities. Based on the results of ANOVA test, then $\mathrm{HO}$ null which says there is no significant difference in attitude among Gen $Z$ of different races/ethnicities is rejected. The study had a mean overall attitude of the Chinese is 5.0760, the mean for the Indians is 5.2339, the mean for the Malays is 5.6860 and 5.7732 min for Bumiputera is 5.7732 . The mean for the Chinese is the lowest and the mean for the Bumiputera is the highest. It can be proved that the Chinese Gen $Z$ have a more negative level of attitude, compared to other races. Gen Z's negative attitude of the Chinese towards the Malay language can be illustrated by Figure 1.3.

\begin{tabular}{|c|c|c|c|c|c|c|}
\hline & $60.00 \%$ & & & & & \\
\hline & $50.00 \%$ & & & & & \\
\hline & $40.00 \%$ & & & & & \\
\hline & $30.00 \%$ & & & & & \\
\hline 胥 & $20.00 \%$ & & & & & \\
\hline త్ర & $10.00 \%$ & & & & & \\
\hline & $0.00 \%$ & SDA & DA & NC & A & SA \\
\hline & alay & $18.80 \%$ & $8.90 \%$ & $10.10 \%$ & $18.60 \%$ & $43.50 \%$ \\
\hline & inese & $34.90 \%$ & $17.10 \%$ & $24.70 \%$ & $15.10 \%$ & $8.20 \%$ \\
\hline & dian & $28.80 \%$ & $13.60 \%$ & $18.60 \%$ & $30.50 \%$ & $8.50 \%$ \\
\hline & umiputera & $12.20 \%$ & $7.30 \%$ & $24.40 \%$ & $48.80 \%$ & $7.30 \%$ \\
\hline
\end{tabular}

Figure 1.3. Frequency percentage of Gen Z's perceptions on item S6 based on race/ethnicity

Furthermore, the study will also look at the course taken in higher education institutions as a factor that is able to shape the attitude of the Malay language among Gen $\mathrm{Z}$. The Chi Square test, $\chi 2=77.525 a, p=0.000<0.05$, as shown in Table 4.15 , indicating that this study have strong evidence to reject the null hypothesis $(\mathrm{HO})$ that said that there was no significant correlation between the different areas of Gen $Z$ with attitudes toward language. Gen Z field of study directly related to their attitudes towards language. However, the value of $\pi(w=0.239)$ indicates that the correlation that occurs is a weak/small correlation. 
Table 1.4. Relationship between the field of study and Gen Z's attitude towards Malay language.

\begin{tabular}{|c|c|c|c|c|c|c|c|c|}
\hline \multirow[t]{2}{*}{ Field of study } & \multicolumn{4}{|c|}{ Malay Language Identity (\%) } & \multirow[t]{2}{*}{ Total } & \multirow[t]{2}{*}{$x^{2}$} & \multirow[t]{2}{*}{$\mathbf{P}$} & \multirow[t]{2}{*}{$\mathbf{w}$} \\
\hline & Fade & $\begin{array}{c}\text { Begin to } \\
\text { Fade }\end{array}$ & High & $\begin{array}{l}\text { Very } \\
\text { High }\end{array}$ & & & & \\
\hline $\begin{array}{l}\text { Engineering } \\
\text { Technology }\end{array}$ & 13.7 & 51.6 & 32.3 & 3.0 & 372 & $113.294^{a}$ & 0.000 & 0.239 \\
\hline $\begin{array}{l}\text { Science \& } \\
\text { Technology }\end{array}$ & 12.5 & 58.3 & 20.8 & 8.3 & 72 & & & \\
\hline Medical & 37.5 & 5.10 & 11.8 & 0.0 & 51 & & & \\
\hline $\begin{array}{l}\text { Economy/ } \\
\text { Business/ } \\
\text { Accounting }\end{array}$ & 18.2 & 39.0 & 40.3 & 2.6 & 77 & & & \\
\hline Communication & 7.8 & 25.5 & 58.8 & 2.5 & 51 & & & \\
\hline $\begin{array}{l}\text { Language \& } \\
\text { Literature }\end{array}$ & 0.0 & 30.0 & 40.0 & 30.0 & 30 & & & \\
\hline Others & 0.0 & 42.9 & 28.6 & 28.6 & 7 & & & \\
\hline
\end{tabular}

Table 1.4 shows that Gen $Z$ who took the medical stream has a more negative attitude towards Malay language followed by those from Science \& Technology. Gen Z who majored in Linguistics \& Literature have a more positive attitude, followed by Communication than those from other fields.

The ANOVA test performed, $F=12.817, p=0.000<0.05$, proved that there are differences in attitudes among Gen Z from different fields of study. Based on PostHoc and Sheffer, the study recorded mean for medicine 4.4647, Science \& Technology 5.4292, Engineering Technology was 5.4446, Economics/Business/Accounting 5.5558, Communication 6.2255, Linguistics \& Literature 6.8333 and others 6.6143 . This finding proves that Gen $Z$ majored in Linguistics \& Literature have a more positive attitude towards languages other than English, compared with Gen Z in other fields. 


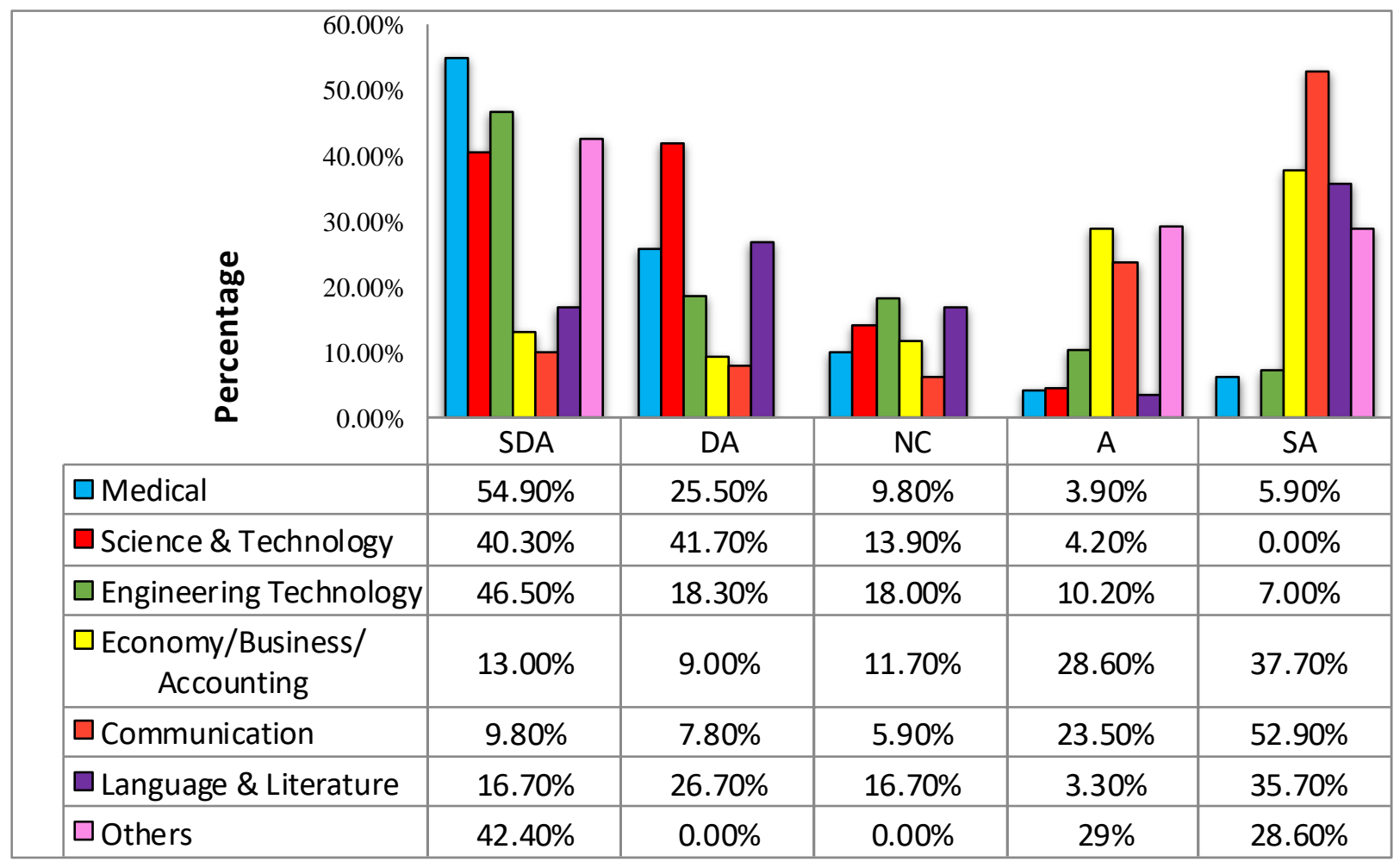

Figure 1.4. Frequency percentage of Gen Z's perceptions on item $\mathrm{S} 6$ based on field of study

\section{Socio-cognitive Analysis of Gen Z Attitude towards Malay Language}

A person's attitude towards Malay language does not built simply by depending on the person's behaviour himself. The constitution of language attitudes in general is also influenced by other factors like background and environment of a speaker. According to Bandura (1986), a person learns through observation, reading the behaviour of other human beings, and makes general assumptions about the world. Bandura believes that behaviour, personal variables and environment will influence the formation of a person's personality. This triangular relationship is called resiprocal determinism. These three elements are interrelated in influencing a person's behaviour. In the context of this study, the attitudes of Gen $Z$ are cognitive elements formed from the influence of their social background. The personality formed from the reaction with the environment when highlighted in the society can be amodel for others to follow. This phenomenon can certainly be explained using appropriate theories.

Thus, this section will specifically explain the phenomenon of Gen Z's identity of the Malay language using Socio-cognitive theory and approach as the basis of the study. The cognitive process involved is to identify the ability of humans (Gen Z) to see the same shape or event occur over and over again. Forms and events that occur repeatedly will be easily absorbed in mind. In life, human beings will usually recall experiences or events that have happened to be a model in making assessments, decisions or choices. According to Wahid (2003), the human ability to recall events that occured is a cognitive process and express back through the action of all experiences to be conveyed to the society. The efficiency of cognitive processes occurs when human beings are able to distinguish betwen one experience with another to shape their personality in life. 
Socio-cognitive theory (Bandura, 1989) which is more prominent in psychology and education is an extension of traditional behavioral learning theory or behaviorism. Initially, this theory was known as Social Learning Theory and sometimes is also known as Social Cognitive Learning Theory. However, in a further development, namely in 1986, this theory was later renamed as Social Cognitive Theory. The main idea of this theory states learning and behavioral change can be done through observation and model replication. Through observation and replication of the model, the learning process and behavioral change can be dome more quickly to the maximum. This is because, through the model, one can observe and distinguish between what should and should not be done. Bandura (1989) mentioned that the observational learning is more efective than direct learning. Though observation, they are able to imitate actions or deeds that should and should not be done easily since they are in a real discourse. Therefore, the process often used in this method is modelling. In general, there are three types of models:

i. Animated model (family members, teachers, peers, etc)

ii. Iconic and symbolic (visual representations such as cartoons, films and televisions).

iii. Textual model or verbal instructions (newspaper and other printed media).

Overall, the study concluded that the Gen $Z$ in the study had the highest negative attitude towards the establishment of the requirement to pass Malay language as the main qualification to get a job in the public sector. Throughout this study, it is found that $80.4 \%$ of Gen $\mathrm{Z}$ in the medical stream believes that the requirement to pass the Malay language as the main condition for getting a job in the public sector is not relevant and should be repealed. These findings illustrate how negative the attitude of this group is towards their own national language. Hence it is not surprising that those in the same field have openly challenged the sovereignty of the Malay language, when the Public Service Department (JPA) agreed with the proposal of the Ministry of Health to loosen the eligibility requirements to pass the Malay language for Sijil Pelajaran Malaysia (SPM) for the post of Medical Officer Grade UD41 by contract. This flexibility will make Malay language seen increasingly marginalized and ignored. This study also showed that Gen Z in Science \& Technology and Engineering Technology also contributes a high percentage in order to abolish the requirement to pass the Malay language as the main condition for getting a job in the public sector. This situation gives the impression that these Gen $Z$ have gone through the process of mimicking the same linguistic events, and eventually gave birth to a group of Gen $Z$ who have similar attitudes towards the national language.

This study found that Gen Z involved in these three areas were born around 1998 to 1999 and is a generation that has undertaken the policy of Teaching and Learning Mathematics and Science in English (PPSMI). This generation has been exposed to the use of English in the education system since they were in Standard 1. Although PPSMI was dissolved in 2012, but this cohort of students are given the option to use the Malay or English as the medium of instruction for Mathematics and Science. This use of English occurs continuously up to the tertiary level. The basis of this PPSMI, has been one of the factors in the process of imitating linguistic events through the principle of attention as contained in socio-cognitive theory. Through the attention given by Gen Z, to the teacher's speech form, language style, the way a word is pronounced during the PdP session will be able to be imitated by them. Based on the socio-cognitive context, the teacher is a animated model that can influence the 
linguistic forms used by Gen Z. Attention to the model, which lasts over a long period of time will make Gen Z more proficient in using English with accurate pronunciation and vocabulary. At the same time, they are experiencing difficulties in using the Malay language well because its practices are declining.

Looking at the distribution of these fields of study based on location, $60.8 \%$ to $73.6 \%$ of Gen Z from these three fields come from urban areas. According to Mohd Isha Awang (2008), people in the city are now being increasingly concerned with English language and it has caused the learning of Malay language to get more challenging. Besides, he also acknowledged that since people tend to have a higher confidence towards English, this has led to a significant change in attitude among students towards Malay language. This circumstance reinforces the findings that the high exposure to the use of English has contributed to the negative attitude towards Malay language. The use of English is higher in urban areas, resulting in Gen Z's attitude to the language. They are exposed to various models to imitate in speaking.

The use of English is indeed high in urban areas. However, due to the expansion of urbanization and advancement broadband network access, those living in suburbs and rural areas are also sharing the benefits. According to Samruhaizad, Jamaluddin \& Azahan (2014), the most suitable area in accommodating the proliferation of urban settlements whether for administrative development, education, industry, residential and commercial business centers that have been planned for the future is suburban areas. The transformation of suburban areas to urban structuring is an effect of the rapid growth of developing metropolitan cities. The community living in the village, began to imitate the language style of the urban community by using English to communicate with small children. Hafiz's report (2016) in Astro Awani reinforces this point. According to the report, the gap in the level of English language use among students in rural and urban schools is getting smaller every year. This news report also quoted the former Minister of Education, Chong Sin Woon who stated that the literacy among students in urban areas was at $89.9 \%$ while in rural areas recorded English literacy at $83.3 \%$.

To ensure their children are not left behind and competitive, parents have prepared their children with a variety of skills, especially English language skills. The respondents in this study were Gen Z, who were born, raised and went through the PPSMI policy. In this case, human behavior is said to occur as a result of the relationship between the environment and the human cognitive schema itself. Gen $Z$ alters their behaviours through strengthening the model of the people around them especially parents and teachers. Gen Z sees the importance of mastering English from parents and the education system. Bandura also argues that children and adolescents learn a lot through imitation. According to him, human behavior results from the experience of parenting children. Therefore, it can be concluded that the language identity of Gen $Z$ is the result of the upbringing and wishes of parents and the national education system.

Furthermore, this study also shows that the Chinese Gen Z recorded a high percentage of $52.0 \%$ who did not agree with the main conditions to enter the public sector. This finding is in line with the study by Nor Hashimah, Junaini \& Mustaffa (2013), which found that more than $30.0 \%$ of Chinese students thought that the dominance of the Malay language to get a 
job is not important. I think that one of the reasons that can be attributed based on the findings of these is, there is Gen Z who did not pass the Malay language in the SPM or not the subject of the Malay language while in school. This group then pursued their studies abroad, or even in private colleges, and they are not concerned with the results of the Malay language. When these people end up learning certain advantages offered, they want to serve in the public sector, but are obstructed because of the constraints of the main requirements to pass the Malay language.

Generally, the relationship that the authors refer to is, Gen Z Chinese, did not take the subject of the Malay language at school, or failed in SPM for the subject. This is because they live in an environment that is not concerned with the background of the Malay language. According to the reciprocal relationship that is the idea of Socio-cognitive theory, a person's personality is shaped by his behavior, personal variables, and environment. These three aspects are interrelated in influencing behavior. In this study, it can be seen that the negative attitudes of Gen Z Chinese on the requirement to pass the Malay language as a qualification for workers in the public sector, is influenced by the family environment, the surrounding community and the educational system adopted by them are not emphasizing on mastering the Malay language. They see people who do not use Malay language and are not fluent in Malay can also be successful, in fact can secure a great career. The things they see through these people around them, give encouragement to these Chinese Gen $Z$ to do the same. The people around followed by Gen $Z$ in this study are imitations of animate models as mentioned in socio-cognitive theory. According to Bandura, human beings are free to respond to situations, they can also be changed and influenced by unexpected circumstances, then these experienced events will shape their personality and determine the direction of their lives (Puteri Roslina, 2003). From a socio-cognitive point of view, this is related to the imitation of the faiths and beliefs of close family members, especially parents. Every race has an ego wanting to protect its own language and heritage. The ideology, way of life, language, beliefs in their traditions have been inculcated from the very beginning, becoming a strong memory in the thinking of Gen Z. Parents and family members serve as animate role models that shape the thinking of Gen $Z$ and are strongly supported by environments that adopt similar life patterns, languages, faiths and beliefs. This situation makes everything that has been the concern of Gen Z since childhood the most right thing in their lives, eventually used as a platform in shaping their attitude towards language.

\section{Conclusion}

Analysis of the relationship between the social background of Gen Z with the attitude of the Malay language shows that social background plays a role in shaping attitudes. The analysis found that social background such as gender, location of residence, race / ethnicity and fields of study indeed have a relationship and a significant difference in the attitude of Malay language among Gen Z. Teenagers' cognitions apparently always change with social conditions and the environment encompassing it. To see the attitude of the Malay language among Gen $\mathrm{Z}$ in detail, some of the items that are considered to provide information on the identity of the language has been tested to the respondents through the questionnaire. The findings have proved that socio-cognitive differences lead to differences in the level of language attitudes. In conclusion, this study has explained the phenomenon attitude Malay language among Gen Z, using Socio-cognitive theory and found that the formation of Gen Z's attitude in this study begins with the process of observing and imitating the behavior of role 
models. Animate role models such as teachers, parents and close family members are the most powerful influence in identity formation for Gen $Z$ to Malay language. Animate role models often respond to Gen $Z$ cognition to shape language attitudes i.e. accept linguistic forms or patterns that occur in society.

\section{Acknowledgement}

I would like to express my heartfelt gratitude to my PhD supervisor who has supervised me with dedication and helped in producing this article. I would like to also thank Faten Khalida Khalid for helping to translate the entire article.

\section{Corresponding Author}

Junaini Kasdan

Universiti Kebangsaan Malaysia (UKM)

Email: junaini@ukm.edu.my

\section{References}

Awang, M. I. (2008). Isu dan Cabaran Bahasa Melayu dalam Pendidikan. Berita Harian. Bandura, A. (1986). Social Faoundations of Thoughts and Action: A Social Cognitive Theory. Englewood Cliffs. NJ.: Prentice-Hall.

Bandura, A. (1989). Human agency in social cognitive theory. American Psychologist, 11751184.

Graf, A. (2020). Cabaran Pelestarian Bahasa Melayu Menjelang Revolusi Industri Keempat. Melayu: Jurnal Antarabangsa Dunia Melayu, 13(1), 161-172. Retrieved from http://jurnal.dbp.my/index.php/Melayu/article/view/5776

Ismail, K., Anwar, K., Ahmad, S., \& Selamat, J. (2010). Profil Personaliti Bakal Calon Majlis Perwakilan Pelajar UKM: Suatu Perbandingan Antara Lelaki Dan Wanita. Jurnal Personalia Pelajar, 13, 1-18.

Jalaluddin, N. H., Kasdan, J., \& Omar, M. (2013). Penguasaan Bahasa Melayu Remaja Sabah dan Sarawak. 1st Edition. Bangi: Universiti Kebangsaan Malaysia

Marzukhi, H. (2016). Jurang Literasi Bahasa Inggeris Antara Bandar dan Luar Bandar Semakin Kecil. astroawani. Retrieved from https://www.astroawani.com/berita-malaysia/jurang-literasi-bahasainggeris-antara-bandar-dan-luar-bandar-semakin-kecil-121801

Noorashid, N. A. (2019). Revolusi industri 4.0: impak terhadap perkembangan pendidikan tinggi di Malaysia. Journal of Sciences and Management Research, 5, 55-67.

Pandian, S. (2017) Harkat bahasa Malaysia. Retrieved from http://www.utusan.com.my/rencana/utama/harkat-bahasa-malaysia1.545093

Razali, A., Ani, F., \& Tohar, S. N. A. M. (2020). Cabaran masyarakat hari ini: Malaysia dalam menghadapi perubahan sosial dan revolusi industri 4.0. In Halim, H., Rameli, N., Rahman, R. (Ed.), Mendepani perubahan sosial dalam era revolusi industri 4.0. (pp. 119). Retrieved from

https://umexpert.um.edu.my/public_view.php?type=publication\&row=OTkxNTk\%3D Sani, K. S. A. (2007). Bahasa Melayu apa sudah jadi? Selangor: PTS Professional Publishing Sdn.Bhd. 
Samian, S., Md. Jahi, J., \& Awang, A. (2014). Isu Perbandaran dan Kualiti Hidup Penduduk Pinggir Bandar. International Journal of the Malay World and Civilisation: IMAN, 2(21): $63-75$

Wahid, P. R. A. (2003). Pendekatan Sosiokognitif dalam Seni Kartun: Kajian Kes Kartun Lat. Jurnal Bahasa, 3: 433-645 